\title{
Schiff Bases of Triethylenetetramine as Corrosion Inhibitors of Zinc in Hydrochloric Acid
}

\author{
M.D. Shah, A.S. Patel, G.V. Mudaliar and N.K. Shah* \\ Chemistry Department, School of Sciences, Gujarat University, Ahmedabad, \\ Gujarat - 380009, India
}

Received 24 September 2010; accepted 29 March 2011

\begin{abstract}
The performance of triethylenetetramine-tribenzylidene (TTTB) and triethylenetetramine-trisalicylidene (TTTS) as corrosion inhibitors for zinc in hydrochloric acid is investigated. At lower concentrations, both inhibitors accelerate the attack but inhibit corrosion at higher concentrations, e.g., 96-100\% with $1.0 \%$ concentration in $0.5 \mathrm{M}$ and $1.0 \mathrm{M} \mathrm{HCl}$. The efficiency of TTTB decreases while that of TTTS remains almost constant $(\geq 99.7 \%)$ up to 120 minutes and in the temperature range $35-65^{\circ} \mathrm{C}$. The activation energies are higher in inhibited than in plain acid with both inhibitors. The free energy of adsorption $\left(\Delta \mathrm{G}_{\mathrm{ads}}\right)$ and heat of adsorption $\left(\mathrm{Q}_{\mathrm{ads}}\right)$ are negative, which suggests that there is spontaneous adsorption on metal surface, and from the values of $\left(\Delta \mathrm{G}_{\mathrm{ads}}\right)$ and $\left(\mathrm{Q}_{\mathrm{ads}}\right)$, the values of entropy of adsorption $\left(\Delta \mathrm{S}_{\mathrm{ads}}\right)$ were calculated. Galvanostatic polarization shows that corrosion is under mixed control with predominance of the cathodic part. In uninhibited $1.0 \mathrm{M} \mathrm{HCl}$, complete cathodic protection is achieved at a current density of $4.2224 \mathrm{Adm}^{-2}$, but in presence of these inhibitors, much lower current densities are required. Plot of $\log (\theta / 1-\theta)$ versus $\log C_{\text {inh }}$ gives a straight line, suggesting that inhibitors cover both the anodic and cathodic regions through general adsorption following Langmuir isotherm. The mechanism of inhibition has been proposed.
\end{abstract}

Keywords: corrosion, zinc, hydrochloric acid, inhibitor.

\section{Introduction}

Zinc is an active metal with numerous industrial applications and is mainly used for the corrosion protection of steel [1-7]. The zinc coated steel materials provide a greater resistance to corrosion but when exposed to humid atmosphere, they undergo rapid corrosion with the formation of a corrosion product known as

\footnotetext{
* Corresponding author. E-mail address: nishchem2004@yahoo.co.in
} 
white rust. The formation of white rust is generally observed in galvanized materials and renders the plated zinc materials unsuitable for industrial applications. Also, industrial processes such as scale removal and cleaning of zinc surfaces with acidic solutions expose zinc to corrosion. Therefore, in order to protect the metal from corrosion, the use of inhibitors is necessary [8].

The Schiff bases as inhibitors can offer a cheap, easy to apply and highly effective method of corrosion control when certain considerations are observed. Therefore, inhibitors have been used for many years to protect metals whose mechanical and physical properties must be retained for long periods of time [9]. A survey of literature [10-15] shows that the substances investigated as inhibitors include benzaldehyde and quinoline derivatives, quaternary salts of pyridine bases, triazoles, benzotriazoles and their derivatives, imidazole azo derivatives, quaternary imidazoline derivative, alkaloids, thiourea, benzenethiol, Schiff bases of chloroanilines and toluidenes and 2-mercaptobenzimidazol. It has also been reported [7,16,17] that the efficiency of Schiff bases is much better than the corresponding amines or aldehydes. In the present work the inhibitor efficiency of triethylenetetramine-tribenzylidene (TTTB) and triethylenetetraminetrisalicylidene (TTTS) for zinc in hydrochloric acid has been reported.

\section{Methods and materials}

\section{Preparation of Schiff bases}

The Schiff bases were synthesized by condensation of triethylenetetramine with the corresponding aldehydes (benzaldehyde and salicylaldehyde) in the presence of ethyl alcohol. The reactants were mixed at $0-5{ }^{\circ} \mathrm{C}$ and the mixture was refluxed on a water bath for an hour. After the completion of the reaction, the reaction mixture was treated with icecold-distilled water, when the crude solid product separated out. It was first washed with water and then with very dilute hydrochloric acid. Finally it was washed with distilled water then purified by repeated crystallization from ethanol [7].

Triethylenetetramine-tribenzylidene (white crystalline substance; m.p., $86{ }^{\circ} \mathrm{C}$ ) and triethylenetetramine-trisalicylidene (yellow crystalline substance; m.p., 105 ${ }^{\circ} \mathrm{C}$ ), are insoluble in water but soluble in ethanol.

The two inhibitors may be represented by the general formula:

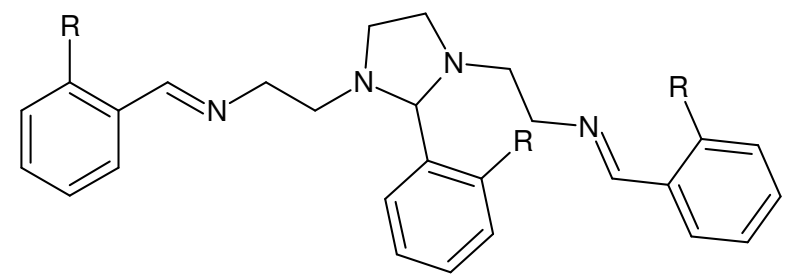

$\mathrm{R}=\mathrm{H}$ in TTTB; and $\mathrm{R}=\mathrm{OH}$ in TTTS 


\section{Preparation of specimens}

Square specimens of zinc, of size $3 \mathrm{~cm} \times 3 \mathrm{~cm}$ (thickness $0.16 \mathrm{~cm}$ ), containing $>99.5 \%$ of the electrolytic zinc were polished to mirror finish, degreased with A.R. carbon tetrachloride (sulphur free), and used for the weight loss method.

For polarization study, metal coupons of circular design, diameter $2.802 \mathrm{~cm}$ with a handle $3 \mathrm{~cm}$ long and $0.5 \mathrm{~cm}$ wide, were used. The working and auxiliary electrodes were coated with Perspex in such a way that only a circular portion having an area of $6.156 \mathrm{~cm}^{2}$ was exposed to the matrix.

\section{Weight loss method}

Zinc specimen was immersed in $230 \mathrm{~mL}$ of the solution containing various concentrations of the inhibitors in the absence and presence of TTTB and TTTS, at $35 \pm 0.5^{\circ} \mathrm{C}$, for an exposure period of 30 minutes. The weight of the specimen before and after immersion was determined using a mettler balance - M5 type. Inhibition efficiency (\%IE) was calculated from the relationship \%IE $=\left(1-\mathrm{W}_{\mathrm{i}} /\right.$ $\left.\mathrm{W}_{\mathrm{u}}\right) \times 100$, where $\mathrm{W}_{\mathrm{u}}=$ weight loss in uninhibited acid, and $\mathrm{W}_{\mathrm{i}}=$ weight loss in inhibited acid.

\section{Polarization study}

Polarization study was carried out using a three electrode cell assembly. Zinc was used as working electrode, platinum as counter electrode and saturated calomel electrode (SCE) as reference electrode. The corrosion parameters such as corrosion potential $\left(\mathrm{E}_{\text {corr }}\right)$, corrosion current $\left(\mathrm{I}_{\text {corr }}\right)$ and Tafel plots were measured. In this study, the current density was varied in the range of $2 \times 10^{-4}$ to $3.25 \times 10^{-2}$ $\mathrm{A} \mathrm{cm}^{-2}$.

\section{Results and discussion \\ Effect of inhibitor concentration}

The results given in Table 1 show that a specimen of zinc immersed in $0.5 \mathrm{M}$ hydrochloric acid suffered a weight loss of $957 \mathrm{mg} \mathrm{dm}^{-2}$ in 30 minutes, whereas that in $1.0 \mathrm{M}$ acid, suffered a weight loss of $3500 \mathrm{mg} \mathrm{dm}^{-2}$ in 30 minutes. The results show that lower concentrations of the inhibitors accelerate the corrosion of zinc. The extent of acceleration at first increases with increase in inhibitor concentration, reaches a maximum, and then decreases in the case of TTTB. And in case of TTTS, acceleration decreases with increasing inhibitor concentration. Thus, $1.0 \%$ concentration of TTTB confers $96.3 \%$ and $97.6 \%$, while TTTS confers $100.0 \%$ and $99.9 \%$ protection to zinc in $0.5 \mathrm{M}$ and $1.0 \mathrm{M} \mathrm{HCl}$, respectively. In $0.5 \mathrm{M} \mathrm{HCl}$, it also appears that there is some threshold concentration, when the inhibition suddenly sets in. A similar behavior is observed in $1.0 \mathrm{M} \mathrm{HCl}$ but the onset of inhibition takes place at higher inhibitor concentrations. At lower concentration of the inhibitor, acceleration occurred, and at higher concentration inhibition is observed. 
Table 1. Effect of inhibitor concentration on weight loss and inhibition efficiency for zinc in $0.5 \mathrm{M}$ and $1.0 \mathrm{M}$ hydrochloric acid. (Temperature: $35 \pm 0.5^{\circ} \mathrm{C}$; exposure period: $30 \mathrm{~min}$.).

\begin{tabular}{|c|c|c|c|c|}
\hline \multirow{2}{*}{$\begin{array}{c}\text { Inhibitor } \\
\text { concentration } \\
(\% \mathrm{~W} / \mathrm{V})\end{array}$} & \multicolumn{2}{|c|}{$0.5 \mathrm{M} \mathrm{HCl}$} & \multicolumn{2}{|c|}{$1.0 \mathrm{M} \mathrm{HCl}$} \\
\hline & $\begin{array}{c}\text { Weight loss } \\
\left(\text { mgdm }^{-2}\right)\end{array}$ & $\begin{array}{c}\text { Inhibition } \\
\text { efficiency }(\%)\end{array}$ & $\begin{array}{c}\text { Weight loss } \\
\left(\text { mgdm }^{-2}\right)\end{array}$ & $\begin{array}{c}\text { Inhibition } \\
\text { efficiency (\%) }\end{array}$ \\
\hline Nil (HCl only) & 957 & - & 3500 & - \\
\hline \multicolumn{5}{|c|}{ Triethylenetetramine-tribenzylidene $(\boldsymbol{T T T B})$} \\
\hline 0.05 & 10444 & -991.3 & 27929 & -698.0 \\
\hline 0.10 & 12711 & -1228.2 & 28493 & -714.1 \\
\hline 0.20 & 12595 & -1216.1 & 28736 & -721.0 \\
\hline 0.30 & 10073 & -952.6 & 28590 & -716.9 \\
\hline 0.50 & 45 & 95.3 & 24176 & -590.7 \\
\hline 0.80 & 40 & 95.8 & 121 & 96.5 \\
\hline 1.00 & 35 & 96.3 & 83 & 97.6 \\
\hline \multicolumn{5}{|c|}{ Triethylenetetramine-trisalicylidene (TTTS) } \\
\hline 0.05 & 10951 & -1044.3 & 28290 & -708.3 \\
\hline 0.10 & 2957 & -209.0 & 27973 & -699.2 \\
\hline 0.20 & 758 & 20.8 & 14084 & -302.4 \\
\hline 0.30 & 15 & 98.4 & 2112 & 39.7 \\
\hline 0.50 & 10 & 99.0 & 20 & 99.4 \\
\hline 0.80 & 10 & 99.0 & 15 & 99.6 \\
\hline 1.00 & 00 & 100.0 & 5 & 99.9 \\
\hline
\end{tabular}

When plots of $\log \theta / 1-\theta$ vs. $\log C_{\text {inh }}$ (inhibitor concentration) (Fig.1) were drawn, straight lines were obtained, indicating that the inhibitors function through adsorption following Langmuir isotherm [18]:

$$
C_{i n h}=\frac{\theta}{K(1-\theta)}
$$

However, when the surface coverage is very high and $\theta$ becomes constant, the plots deviate and run parallel to the abscissa.

\section{Effect of exposure period}

The effect of exposure period on inhibitive efficiency of TTTB and TTTS at 35 ${ }^{\circ} \mathrm{C}$ and $1.0 \%$ concentration was studied. From the results (Table 2), it is evident that as the exposure period is increased from 30 minutes to 120 minutes, the loss in weight in uninhibited $0.5 \mathrm{M}$ hydrochloric acid increases from $957 \mathrm{mg} \mathrm{dm}^{-2}$ to $4848 \mathrm{mg} \mathrm{dm}^{-2}$, and from $3500 \mathrm{mg} \mathrm{dm}^{-2}$ to $24051 \mathrm{mg} \mathrm{dm}^{-2}$ in $1.0 \mathrm{M}$ acid.

The difference in the inhibitive efficiency of TTTB and TTTS is effectively reflected in $0.5 \mathrm{M}$ hydrochloric acid, which is a little more corrosive compared to $1.0 \mathrm{M} \mathrm{HCl}$. The inhibitor efficiency of TTTB in $0.5 \mathrm{M} \mathrm{HCl}$ decreases from 96.3\% for 30 minutes to $95.9 \%$ for 120 minutes and that of TTTS decreases from $100.0 \%$ for 30 minutes to $98.8 \%$ for 120 minutes. In $1.0 \mathrm{M} \mathrm{HCl}$, TTTS shows a very high efficiency of $99.7 \%$ for exposure periods extending up to two hours, i.e., as compared to TTTB, TTTS is more effective. 


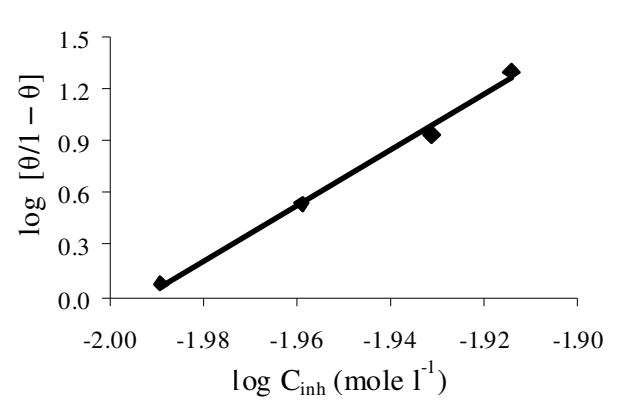

(a)

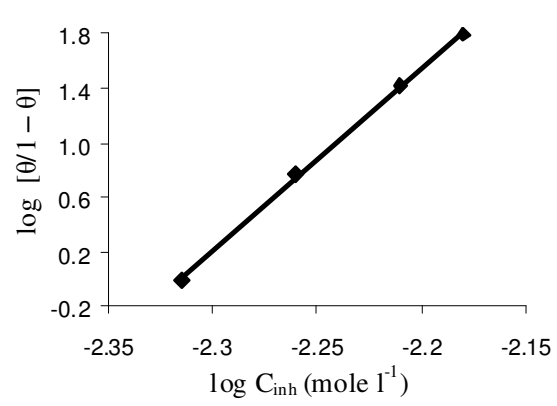

(b)

Figure 1. Langmuir plots for Schiff bases in $0.5 \mathrm{M}$ hydrochloric acid at $35^{\circ} \mathrm{C}$. (a) TTTB and (b) TTTS.

Table 2. Effect of exposure period on weight loss and inhibitor efficiency for zinc in hydrochloric acid containing different inhibitors. (Temperature: $35 \pm 0.5{ }^{\circ} \mathrm{C}$; inhibitor concentration: $1.0 \%(\mathrm{~W} / \mathrm{V})$ ).

\begin{tabular}{ccccccc}
\hline \multirow{2}{*}{ Inhibitor } & \multicolumn{3}{c}{$\%$ Inhibition in 0.5 M HCl } & \multicolumn{3}{c}{ \% Inhibition in 1.0 M HCl } \\
\cline { 2 - 7 } & $30 \mathrm{~min}$ & $60 \mathrm{~min}$ & $120 \mathrm{~min}$ & $30 \mathrm{~min}$ & $60 \mathrm{~min}$ & $120 \mathrm{~min}$ \\
\hline \multirow{2}{*}{ TTTB } & 35 & 73 & 201 & 83 & 95 & 299 \\
& $(96.3 \%)$ & $(96.5 \%)$ & $(95.9 \%)$ & $(97.6 \%)$ & $(99.2 \%)$ & $(98.6 \%)$ \\
& 00 & 13 & 58 & 5 & 15 & 95 \\
TTTS & $(100 \%)$ & $(99.4 \%)$ & $(98.8 \%)$ & $(99.9 \%)$ & $(99.9 \%)$ & $(99.7 \%)$
\end{tabular}

From the weight loss data, it may be generalized that where corrosion protection is desired for longer exposure periods, TTTS shows better performance. The result also shows that the incorporation of $-\mathrm{OH}$ group in o-position in the benzylidinic-part of the Schiff base has better effect on the inhibitive efficiency of TTTS, particularly for longer exposure periods.

\section{Effect of temperature}

To determine the effect of temperature on inhibitive efficiency, weight losses were determined in $1.0 \mathrm{M} \mathrm{HCl}$ containing $1.0 \%$ of TTTB, and $0.4 \%$ and $0.5 \%$ of TTTS at solution temperatures of $35,45,55$ and $65^{\circ} \mathrm{C}$ for an exposure period of 60 minutes. From the results given in Table 3, it is evident that the extent of corrosion in inhibited as well as in uninhibited acid increases with a rise in temperature, the loss in weight being much higher in plain acid. The extent of inhibition is ranging from $95.1 \%$ (1.0\% of TTTB) to $99.3 \%$ ( $0.5 \%$ of TTTS).

The $E_{a}$ values have been calculated from the plots of $\log \rho$ (log corrosion rate, $\mathrm{mg} \mathrm{dm}{ }^{-2}$ ) vs. ${ }^{1} / \mathrm{T}$ (Fig. 2) and are given in Table 3. From the $\mathrm{E}_{\mathrm{a}}$ values, it is apparent that for the corrosion of zinc in uninhibited acid the $\mathrm{E}_{\mathrm{a}}$ value is 23.0 $\mathrm{kJmol}^{-1}$, whereas in inhibited acid the values are higher $\left(73.2 \mathrm{kJmol}^{-1}\right.$ for $1.0 \%$ TTTB, $82.8 \mathrm{kJmol}^{-1}$ for $0.4 \%$ of TTTS and $71.1 \mathrm{kJmol}^{-1}$ for $0.5 \%$ of TTTS). In inhibited acid, the $\mathrm{E}_{\mathrm{a}}$ values thus vary and depend on the inhibitive power of the 
inhibitor. It appears that the exponential term in the Arrhenius equation appreciably changes the $\mathrm{E}_{\mathrm{a}}$ value with a slight change in the corrosion rate.

Table 3. Effect of temperature on weight loss and inhibitor efficiency for zinc in $1.0 \mathrm{M}$ hydrochloric acid. (Exposure period: 60 min.; values in brackets show inhibition \%).

\begin{tabular}{|c|c|c|c|c|c|}
\hline \multirow{2}{*}{$\begin{array}{c}\text { Inhibitor } \\
\text { Concentration } \\
(\% \mathrm{~W} / \mathrm{V})\end{array}$} & \multicolumn{4}{|c|}{ Weight loss $\left(\mathrm{mgdm}^{-2}\right)$ at a temperature of } & \multirow{2}{*}{$\begin{array}{c}\mathrm{E}_{\mathrm{a}} \\
\mathrm{kJ} / \mathrm{mole}\end{array}$} \\
\hline & $35^{\circ} \mathrm{C}$ & $45^{\circ} \mathrm{C}$ & $55^{\circ} \mathrm{C}$ & $65^{\circ} \mathrm{C}$ & \\
\hline Nil & 11252 & 16058 & 20299 & 25424 & 23.0 \\
\hline ТTTВ $(1.0 \%)$ & $95(99.2 \%)$ & $166(99.0 \%)$ & $371(98.2 \%)$ & $1240(95.1 \%)$ & 73.2 \\
\hline TTTS $(0.4 \%)$ & $52(99.5 \%)$ & $137(99.1 \%)$ & $437(97.8 \%)$ & $858(96.6 \%)$ & 82.8 \\
\hline TTTS $(0.5 \%)$ & $15(99.9 \%)$ & $30(99.8 \%)$ & $77(99.6 \%)$ & $171(99.3 \%)$ & 71.1 \\
\hline
\end{tabular}

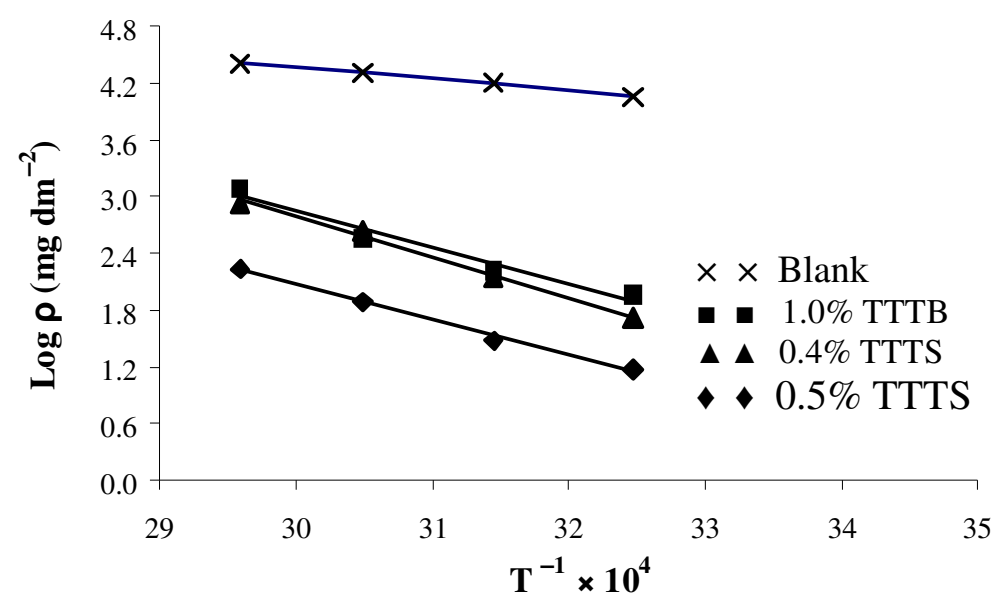

Figure 2. Arrhenius plots for zinc in $1.0 \mathrm{M}$ hydrochloric acid in the presence and absence of inhibitors.

The higher values of activation energy in inhibited acid suggest that the adsorption of the inhibitor on the metal surface may be physical or weak in nature [19]. The efficiency of the inhibitor decreases with increase in temperature. The activation energies are higher in inhibited than in uninhibited acid. $\mathrm{E}_{\mathrm{a}}$ decreases with an increase in inhibitor concentration and temperature due to physisorption. The same behavior mentioned above was also observed by Putilova et al. [20].

\section{Thermodynamic parameters}

The heat of adsorption, $\left(\mathrm{Q}_{\mathrm{ads}}\right)$, was calculated following Hoar and Holiday equation [21], while the free energy of adsorption, $\left(\Delta \mathrm{G}_{\mathrm{ads}}\right)$, was calculated as given by Vashi et al. [22]. From the values of $\left(\mathrm{Q}_{\mathrm{ads}}\right)$ and $\left(\Delta \mathrm{G}_{\mathrm{ads}}\right)$, the values of entropy of adsorption $\left(\Delta \mathrm{S}_{\mathrm{ads}}\right)$ were also calculated. The results given in Table 4 
show that the $\left(\mathrm{Q}_{\mathrm{ads}}\right)$ and $\left(\Delta \mathrm{G}_{\mathrm{ads}}\right)$ values are negative for both the inhibitors. The $\mathrm{Q}_{\mathrm{ads}}$ values are more negative for an efficient inhibitor, which suggests a strong interaction of the inhibitor molecules with the metal surface resulting in the spontaneous adsorption, and also indicates that the adsorption of these two inhibitors on the zinc surface is exothermic.

The values of free energy of adsorption $\left(\Delta \mathrm{G}_{\mathrm{ads}}\right)$ around $-20 \mathrm{KJmol}^{-1}$ or lower are consistent with physisorption, while those around $-40 \mathrm{KJmol}^{-1}$ or higher involve chemisorption [10]; it also suggests that adsorption of the inhibitor is a spontaneous process [23]. Almost similar values (in case of TTTB and TTTS) of $\left(\Delta \mathrm{G}_{\mathrm{ads}}\right)$ also suggest that the two inhibitors are almost equally bonded to the metal surface. The values of entropy of adsorption $\left(\Delta S_{\text {ads }}\right)$ are positive and the values are higher in case of TTTS and show a tendency to decrease with an increase in inhibitor concentration. The results show that a good inhibitor is characterized by negative value of free energy of adsorption, positive value of entropy of adsorption and higher (more negative) heat of adsorption.

Table 4. Free energy of adsorption $\Delta \mathrm{G}_{\mathrm{ads}}$, entropy of adsorption $\Delta \mathrm{S}_{\mathrm{ads}}$ and heat of adsorption $\mathrm{Q}_{\mathrm{ads}}$ for the corrosion of zinc in $1.0 \mathrm{M}$ hydrochloric acid. (Exposure period: $60 \mathrm{~min}$; temperature range: $35-65^{\circ} \mathrm{C}$ ).

\begin{tabular}{cccc}
\hline $\begin{array}{c}\text { Inhibitor and its } \\
\text { concentration }\end{array}$ & $\begin{array}{c}\Delta \mathbf{G}_{\text {ads }} \\
\left(\mathbf{k J m o l}^{\mathbf{1}}\right)\end{array}$ & $\begin{array}{c}\Delta \mathbf{S}_{\text {ads }} \\
\left(\mathbf{J m o l}^{-1}\right)\end{array}$ & $\begin{array}{c}\mathbf{Q}_{\text {ads }} \\
\left(\mathbf{k J m o l}^{-\mathbf{1}}\right)\end{array}$ \\
\hline TTTB (1.0\%) & -31.3 & 261.5 & -52.7 \\
TTTS (0.4\%) & -35.1 & 294.9 & -60.2 \\
TTTS (0.5\%) & -38.9 & 269.8 & -48.5 \\
\hline
\end{tabular}

\section{Polarization behavior}

The influence of current density on the cathodic and anodic potentials of zinc in 1.0 $\mathrm{M}$ hydrochloric acid in the presence and absence of inhibitors is shown in Fig. 3. The galvanostatic polarization data show that TTTB and TTTS are mixed type inhibitors with predominant action on local cathodes. The corrosion potential $\left(\mathrm{E}_{\mathrm{corr}}\right)$ of zinc in $1.0 \mathrm{M}$ hydrochloric acid is $-1048 \mathrm{mV}$ with reference to SCE. Tafel plots efficiencies agree well with those obtained from weight loss data.

At effective concentrations of TTTB $(0.8 \%)$ and TTTS $(0.5 \%)$, both the cathode and anode are polarized, but the cathode is significantly polarized to a much greater extent. With both the inhibitors at effective concentrations, there is a sudden shift in the cathode polarization and the cathode polarization curve shifts in such a manner that it intersects the corrosion potential at very low current density. At $0.8 \%$ of TTTB in $1.0 \mathrm{M} \mathrm{HCl}$, the corrosion of zinc is protected to an extent of $96.5 \%$ (from weight loss data). Similar protection has been observed both from extrapolation of cathodic Tafel line or from the extrapolation of the anodic Tafel line to corrosion potential. This may indicate that TTTB is a mixed one. In the presence of $0.5 \%$ TTTS in $1.0 \mathrm{M} \mathrm{HCl}$, the corrosion of zinc is 
protected to an extent of $99 \%$ (from loss in weight data). $99 \%$ inhibition efficiency is also obtained from the extrapolation of the cathodic Tafel line to $\mathrm{E}_{\text {corr }}$ and $66 \%$ inhibition efficiency is obtained from the extrapolation of the anodic Tafel line to $\mathrm{E}_{\text {corr }}$. This may again indicate that TTTS is a mixed type with predominance on cathodic part.

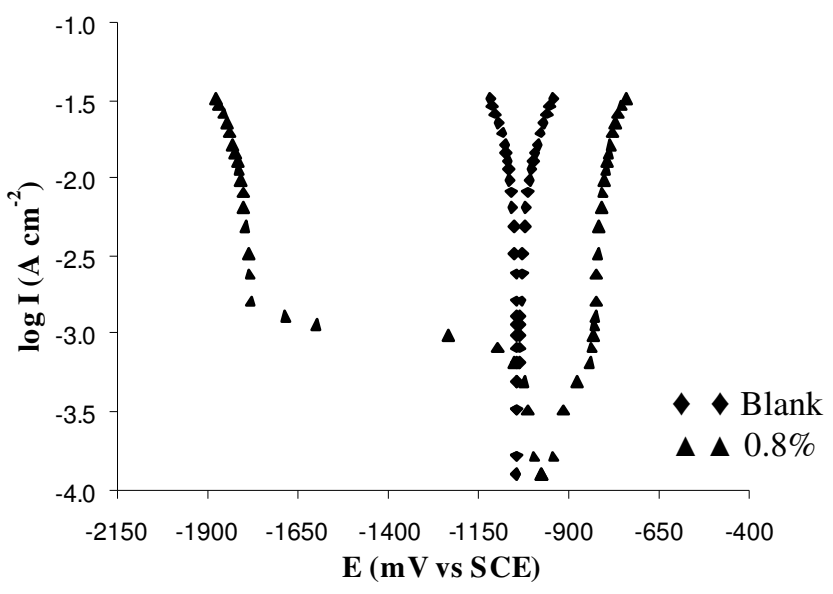

(a)

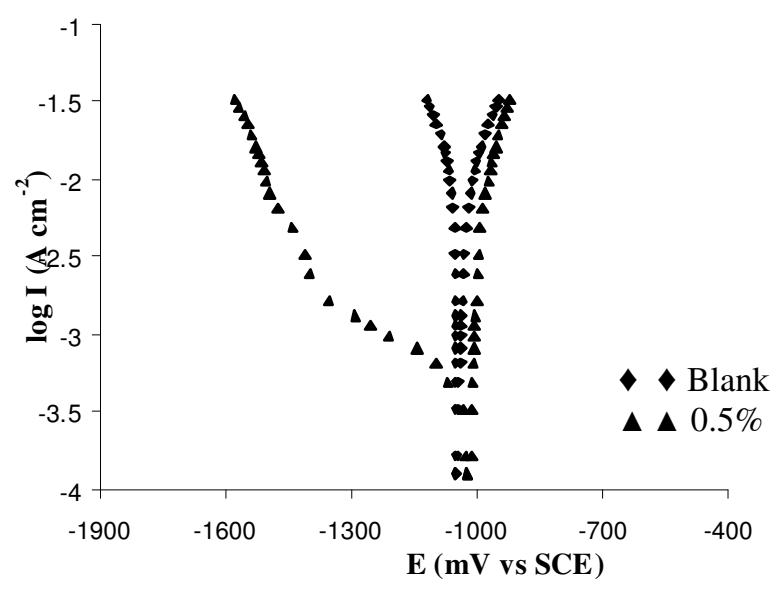

(b)

Figure 3. Effect of current density on the cathodic and anodic potentials of zinc in 1.0 M hydrochloric acid alone and in the presence of inhibitors. (a) TTTB and (b) TTTS.

In Table 5, Tafel parameters and inhibitor efficiencies of TTTB and TTTS for zinc in $1.0 \mathrm{M} \mathrm{HCl}$ are given. It is to be noted that at higher concentrations of TTTB and TTTS, the corrosion of zinc is inhibited. The inhibition obtained from extrapolation of the cathodic Tafel line compares excellently well with the efficiency obtained from weight loss data (30 minutes). This may again indicate that TTTB and TTTS are mixed type inhibitors with predominant effect on the cathode. 
Table 5. Tafel parameters and inhibition efficiencies at higher concentrations of TTTB and TTTS for zinc in $1.0 \mathrm{M}$ hydrochloric acid. (Temperature: $35^{\circ} \mathrm{C} \pm 0.5^{\circ} \mathrm{C}$ ).

\begin{tabular}{|c|c|c|c|c|c|c|c|}
\hline \multirow{2}{*}{$\begin{array}{c}\text { Inhibitor and } \\
\text { its } \\
\text { concentration } \\
(\% \mathrm{~W} / \mathrm{V})\end{array}$} & \multicolumn{2}{|c|}{ Tafel slope b } & \multicolumn{2}{|c|}{$\begin{array}{c}\text { Corrosion current, } \mathrm{A} / \mathrm{cm}^{2} \\
\text { from }\end{array}$} & \multicolumn{3}{|c|}{$\begin{array}{l}\text { Inhibition efficiency (\%) } \\
\text { from }\end{array}$} \\
\hline & $\begin{array}{c}\text { Anodic } \\
\left(\mathbf{b}_{\mathbf{a}}\right) \text { V/decade }\end{array}$ & $\begin{array}{c}\text { Cathodic } \\
\left(\mathbf{b}_{\mathbf{c}}\right) \text { V/decade }\end{array}$ & $\begin{array}{c}\text { Extrapolation } \\
\text { of cathodic } \\
\text { Tafel line at } \\
\text { E }_{\text {corr }}\end{array}$ & $\begin{array}{c}\text { Extrapolation } \\
\text { of anodic } \\
\text { Tafel line at } \\
\mathbf{E}_{\text {corr }}\end{array}$ & $\begin{array}{c}\text { From } \\
\text { (4) }\end{array}$ & $\begin{array}{c}\text { From } \\
\text { (5) }\end{array}$ & $\begin{array}{c}\text { Weight } \\
\text { loss data } \\
\text { (30 min) }\end{array}$ \\
\hline 1 & 2 & 3 & 4 & 5 & 6 & 7 & 8 \\
\hline $\mathrm{Nil}$ (only $\mathrm{HCl}$ ) & 0.124 & 0.108 & $7.9 \times 10^{-3}$ & $5.1 \times 10^{-3}$ & - & - & - \\
\hline ТTTВ $(0.8 \%)$ & 0.087 & 0.138 & $1.0 \times 10^{-8}$ & $1.0 \times 10^{-4}$ & $>99.9$ & 98.0 & 96.5 \\
\hline TTTS $(0.5 \%)$ & 0.061 & 0.126 & $1.6 \times 10^{-6}$ & $1.6 \times 10^{-3}$ & $>99.9$ & 66.6 & 99.4 \\
\hline
\end{tabular}

\section{Cathodic protection}

When an external cathodic current was applied to zinc in uninhibited $1.0 \mathrm{M} \mathrm{HCl}$, complete cathodic protection could be achieved at a current density of 4.2224 $\mathrm{Adm}^{-2}$ (Table-6). In inhibited acid the protective currents are less than those in uninhibited solutions and the reduction in current requirements is greater, the higher the inhibitor concentration.

In the case of TTTB and TTTS which accelerate the corrosion at $0.1 \%$ concentration, complete protection could be achieved with current densities of 3.7352 and $2.2736 \mathrm{Adm}^{-2}$, respectively, the corresponding reduction in current requirements being $11.5 \%$ and $46.2 \%$. With $0.8 \%$ TTTB, complete protection is achieved at the current density of $0.0487 \mathrm{Adm}^{-2}$, which corresponds to $98.8 \%$ reduction in the current requirement. TTTS confers $39.7 \%$ protection at $0.3 \%$ concentration without any applied current, but it inhibits the corrosion completely at a current density of $0.1299 \mathrm{Adm}^{-2}$, i.e., the current requirement is reduced by $96.9 \%$ of that in uninhibited acid. Thus, the adsorption characteristics of the inhibitor are so changed under the influence of the current that it covers greater areas of the metal surface.

Table 6. Weight loss in the absence and presence of protective cathodic current, protective potentials and inhibition efficiencies with zinc in $1.0 \mathrm{M}$ hydrochloric acid. (Exposure period: 30 min.; temperature: $35^{\circ} \mathrm{C} \pm 0.5{ }^{\circ} \mathrm{C}$ ).

\begin{tabular}{|c|c|c|c|c|c|c|}
\hline \multirow[b]{2}{*}{$\begin{array}{c}\text { Inhibitor } \\
\text { and its } \\
\text { concentration } \\
(\% \mathrm{~W} / \mathrm{V})\end{array}$} & \multicolumn{3}{|c|}{ Without external cathodic current } & \multicolumn{3}{|c|}{ With external cathodic current } \\
\hline & $\begin{array}{c}\text { Weight } \\
\text { loss } \\
\text { mgdm }^{-2}\end{array}$ & $\begin{array}{c}\text { Inhibition } \\
\text { efficiency } \\
(\%)\end{array}$ & $\begin{array}{c}\mathbf{E}_{\text {corr }}, \mathbf{m V} \\
\text { (vS. } \\
\text { S.C.E.) }\end{array}$ & $\begin{array}{l}\text { Current } \\
\text { for } \\
\text { complete } \\
\text { protection } \\
\text { Adm }^{-2}\left(\mathbf{i}_{\mathrm{p}}\right) \\
\end{array}$ & $\begin{array}{c}\% \\
\text { Reduction } \\
\text { in current } \\
\text { due to } \\
\text { inhibitor }\end{array}$ & $\begin{array}{c}\text { Protective } \\
\text { potential } \\
\left(\mathbf{E}_{\mathrm{p}}\right), \mathrm{mV} \\
\text { (vs. } \\
\text { S.C.E. })\end{array}$ \\
\hline & & & & 4.2224 & & -1337 \\
\hline & 20 & & & & 11. & -1 \\
\hline TTTB $\left(0.8^{c}\right.$ & 121 & 96 & -927 & 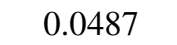 & 98. & -1463 \\
\hline TTTS $(0.1 \%)$ & 27973 & -699.2 & -921 & 2.2736 & 46.2 & -1546 \\
\hline TTTS $(0.3 \%)$ & 2112 & 39.7 & -984 & 0.1299 & 96.9 & -1474 \\
\hline
\end{tabular}

If $I_{o}$ is the inhibitive efficiency without current, $I_{1}$ is the percent protection at the various current densities in uninhibited acid, and $\mathrm{I}_{\mathrm{obs}}$ is the total protection due to 
the conjoint action of the current and the inhibitor, then the conjoint effect may be considered as:

(i) synergistic, if $\mathrm{I}_{\mathrm{obs}}>\left(\mathrm{I}_{\mathrm{o}}+\mathrm{I}_{1}\right)$;

(ii) additive, if $\mathrm{I}_{\mathrm{obs}} \approx\left(\mathrm{I}_{\mathrm{o}}+\mathrm{I}_{1}\right)$;

(iii) antagonistic, if $\mathrm{I}_{\mathrm{obs}}<\left(\mathrm{I}_{\mathrm{o}}+\mathrm{I}_{1}\right)$.

The conjoint effect of external cathodic current and these inhibitors is observed to be either synergistic, or additive, or antagonistic (Table 7). In the present case, the total protection due to the conjoint action of the current and inhibitor is found to be greater than the sum of the protection conferred by each of the individual factors. This suggests that under the influence of an external cathodic current, the adsorption characteristics of the inhibitor are so improved that an accelerator of corrosion functions as an inhibitor. The results are in conformity with Machu [24], Hackermann [25], and also Antropov [26].

Table 7. Conjoint action of inhibitor and cathodic current on the corrosion of zinc in 1.0 $\mathrm{M}$ hydrochloric acid containing inhibitors. (Exposure period: $30 \mathrm{~min}$; ; temperature: 35 $\left.{ }^{\circ} \mathrm{C} \pm 0.5^{\circ} \mathrm{C}\right)$.

\begin{tabular}{|c|c|c|c|c|c|c|}
\hline $\begin{array}{c}\text { Inhibitor and } \\
\text { its } \\
\text { concentration } \\
(\% \mathrm{~W} / \mathrm{V})\end{array}$ & $\begin{array}{c}\text { Applied } \\
\text { current } \\
\text { density } \\
\text { Adm }^{-2}\end{array}$ & $\begin{array}{l}\text { Weight } \\
\text { loss in } \\
\text { inhibited } \\
\text { acid } \\
\text { mgdm }^{-2}\end{array}$ & $\begin{array}{l}\text { Protection } \\
(\%) \text { due to } \\
\text { current in } \\
\text { plain acid } \\
\quad I_{1}\end{array}$ & $\begin{array}{c}\text { Observed } \\
\text { protection } \\
(\%) \text { due to } \\
\text { current } \\
\text { +inhibitor } \\
\text { I }_{\text {obs }}\end{array}$ & $\mathbf{I}_{0}+\mathbf{I}_{1}$ & $\begin{array}{c}\text { Conjoint } \\
\text { action } \\
\left\{\mathbf{I}_{\text {obs }}-\left(\mathbf{I}_{0}+\mathbf{I}_{1}\right)\right\}\end{array}$ \\
\hline 1 & 2 & 3 & 4 & 5 & 6 & 7 \\
\hline Nil & Nil & 3500 & -- & -- & -- & -- \\
\hline \multicolumn{7}{|c|}{ Triethylenetetramine-tribenzylidene (TTTB) } \\
\hline \multirow[t]{5}{*}{0.1} & 0.0000 & 27973 & - & $-699.2\left(\mathrm{I}_{\mathrm{o}}\right)$ & - & - \\
\hline & 0.8120 & 27323 & 34.7 & -680.7 & -664.5 & -16.2 (Ant) \\
\hline & 1.6240 & 26235 & 57.3 & -649.6 & -641.9 & -7.7 (Ant) \\
\hline & 2.1924 & 2989 & 65.6 & 14.6 & -633.6 & 648.2(Syn) \\
\hline & 2.2736 & 00 & 66.7 & 100.0 & -632.5 & 732.5(Syn) \\
\hline \multirow[t]{4}{*}{0.3} & 0.0000 & 2112 & - & $39.7\left(I_{0}\right)$ & - & - \\
\hline & 0.0812 & 1754 & 2.5 & 49.9 & 42.2 & 7.7(Syn) \\
\hline & 0.0974 & 536 & 3.9 & 84.7 & 43.6 & 41.1(Syn) \\
\hline & 0.1299 & 00 & 5.8 & 100.0 & 45.5 & 54.5(Syn) \\
\hline \multicolumn{7}{|c|}{ Triethylenetetramine-trisalicylidene (TTTS) } \\
\hline \multirow[t]{6}{*}{0.1} & 0.0000 & 28493 & - & $-714.1\left(\mathrm{I}_{\mathrm{o}}\right)$ & - & - \\
\hline & 0.8120 & 27924 & 34.7 & -697.8 & -679.4 & $-18.4($ Ant $)$ \\
\hline & 2.4360 & 26430 & 68.9 & -655.1 & -645.2 & -9.9 (Ant) \\
\hline & 3.2480 & 25699 & 82.6 & -634.3 & -631.5 & -2.8 (Add) \\
\hline & 3.7027 & 520 & 94.0 & 85.1 & -620.1 & 705.2(Syn) \\
\hline & 3.7352 & 00 & 94.5 & 100.0 & -619.6 & 719.6(Syn) \\
\hline \multirow[t]{3}{*}{0.8} & 0.0000 & 121 & - & $96.5\left(\mathrm{I}_{\mathrm{o}}\right)$ & - & - \\
\hline & 0.0325 & 33 & 1.1 & 99.1 & 97.6 & $1.5($ Add $)$ \\
\hline & 0.0487 & 00 & 1.6 & 100.0 & 98.1 & 1.9 (Add) \\
\hline
\end{tabular}

\section{Mechanism of inhibition}

Both TTTB and TTTS contain eleven conjugated double bonds (three in each of the aromatic rings and two in the iminic group) and have five anchoring sites (two iminic $>C=N-$, and three aromatic rings). The plots of $\log \theta / 1-\theta$ vs. $\log C_{i n h}$ are found to be linear, which indicates that the inhibitors function through adsorption following Langmuir isotherm. As suggested by Hackermann and 
Kaesche [27], it is likely that the cationic form of the inhibitor or its free base may be adsorbed. Further, the $\pi$-electrons of the aromatic ring will help the inhibitor molecule to get anchored on the anodic areas of the metal surface. Thus, the inhibitor would cover both the anodic as well as the cathodic areas and functions as a mixed type inhibitor.

The better inhibitive power of the inhibitors, when present in adequate amounts, may be traced to the preferential adsorption through the iminic group. The higher and almost constant efficiency of TTTS in the temperature range 35 to $65{ }^{\circ} \mathrm{C}$ may be due to the presence of the $-\mathrm{OH}$ group in the ortho-position, which would facilitate the formation of a six-membered chelate of the type

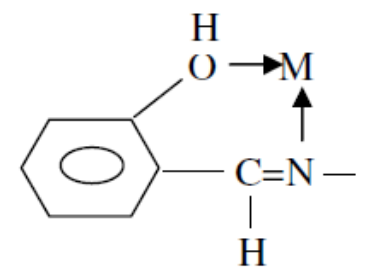

and help the chemisorption process. According to March [28], the $-\mathrm{OH}$ group with $+\mathrm{R},-\mathrm{I}$ effect will change the electron density and activate the aromatic ring.

\section{Conclusions}

1. TTTB and TTTS confer more than $96 \%$ protection to zinc in hydrochloric acid under a variety of conditions.

2. Between the two inhibitors, the efficiency of TTTS remains almost constant, while that of TTTB decreases with increase in the exposure period and temperature. This suggests that TTTS functions through chemisorption and TTTB functions through physisorption (weak adsorption bond).

3. It appears that an efficient inhibitor is characterized by negative value of free energy of adsorption, positive value of entropy of adsorption and higher (more negative) heat of adsorption.

4. The galvanostatic polarization data indicate that these are mixed type inhibitors with predominant effect on the cathode.

5. Cathodic protection in the presence of these inhibitors is achieved at potentials much less negative than that for plain acid. The protective potential corresponding to the protective current is not a constant value and varies with each system. The protective potential changes with the inhibitor concentration.

6. TTTS behaves as an efficient inhibitor because-OH group in ortho-position would facilitate the formation of a chelate having a six-membered ring.

\section{Acknowledgement}

M.D. Shah, A.S. Patel and G.V. Mudaliar are grateful to Chemistry Department, School of Sciences, Gujarat University, Gujarat, for laboratory facility. One of the authors, Aesha Patel is also thankful to UGC-BSR for research fellowship. 


\section{References}

1. B.S. Shylesha, T.V. Venkatesha, B.M. Praveen, J. Chem. Pharm. Res. 3 (2011) 501.

2. S.K. Rajappa, T.V. Venkatesha, B.M. Praveen, Bull. Mater. Sci. 31 (2008) 37. 10.1007/s12034-008-0007-3

3. J. Dobryszycki, S. Biallozor, Corrosion Sci. $43 \quad$ (2001) 1309. 10.1016/S0010-938X(00)00155-4

4. M. Masamitsu, Coating Technol. 34 (1999) 378.

5. A.A. Ahmed, S. Abdel-Hakam, Anti-Corros. Methods Mater. 36 (1989) 4. 10.1108/eb020735

6. K. Aramaki, Corrosion Sci. 44 (2002) 871. 10.1016/S0010938X(01)00087-7

7. Y.K. Agrawal, J.D. Talati, M.D. Shah, M.N. Desai, N.K. Shah, Corrosion Sci. 46 (2004) 633. 10.1016/S0010-938X(03)00174-4

8. N.O. Eddy, S.A. Odoemelam, E.C. Ogoko, B.I. Ita, Port. Electrochim. Acta 28 (2010) 15.10.4152/pea.201001015

9. Magdalena Nunez, 'Prevention of Metal Corrosion: New Research', New York (2005) 8,9.

10. B. Joseph, S. John, A. Joseph, B. Narayana, Indian J. Chem. Technol. 17 (2010) 366.

11. P.C. Okafor, Y. Zheng, Corros. Sci. $51 \quad$ (2009) 850. 10.1016/j.corsci.2009.01.027

12. A.M. Shams El Din, A.A. El Hosary, R.M. Saleh, J.M. Abd El-Kader, Werkst. Korros. 28 (1977) 26. 10.1002/maco.19770280107

13. M.S. Abdel Aal, A.A. Abdel Wahab, A. El. Saied, Corrosion (NACE) 37 (1981) 557.

14. M.N. Desai, P.O. Chauhan, N.K. Shah: $7^{\text {th }}$ Symposium on Corrosion Inhibitors, Ferrara, Italy (1990); $8^{\text {th }}$ Symposium on Corrosion Inhibitors, Ferrara, Italy (1995).

15. L. Wang, J.X. Pu, H.C. Luo, Corrosion Sci. 45 (2003) 677. 10.1016/S0010938X(02)00145-2

16. M.N. Desai, J.D. Talati, N.K. Shah, Indian J. Chem. 42 (A) (2003) 3027.

17. J.D. Talati, M.N. Desai, N.K. Shah, Anti-Corros. Methods Mater. 52 (2005) 108. 10.1108/00035590510584825

18. M.N. Desai, J.D. Talati, N.K. Shah, Anti-Corros. Methods Mater. 55 (2008) 27. 10.1108/00035590810842807

19. N. Soltani, M. Behpour, S.M. Ghoreishi, H. Naeimi, Corros. Sci. 52 (2010) 1351. 10.1016/j.corsci.2009.11.045

20. I.N. Putilova, S.A. Balezin, V.P. Barannik, 'Metallic corrosion inhibitors' (Pergamon Press, New York) (1960) 31.

21. T.P. Hoar, R.P. Holiday, J. Appl. Chem. 3 (1963) 503.

22. R.T. Vashi, H.M. Bhajiwala, S.A. Desai, E-Journal Chem. 7 (2010) 665.

23. N. Caliskan, E. Akbas, Mater. Chem. Phys. $126 \quad$ (2011) 983. 10.1016/j.matchemphys.2010.11.051

24. W. Machu, Werkst. Korros. 21 (1970) 712. 10.1002/maco.19700210905

25. N. Hackermann, A. Brasunas, (Ed) NACE Basic Corrosion Course, NACE, Houston (1970) 9. 
26. L.I. Antropov, 'Proceedings of First International Congress on Metallic Corrosion', London (1961), Butterworths, London (1962) 146.

27. N. Hackermann, H. Kaesche, J. Electrochem. Soc. 105 (1958) 191. $10.1149 / 1.2428796$

28. J. March, 'Advanced Organic Chemistry', John Wiley and Sons, New York (1992) 36. 